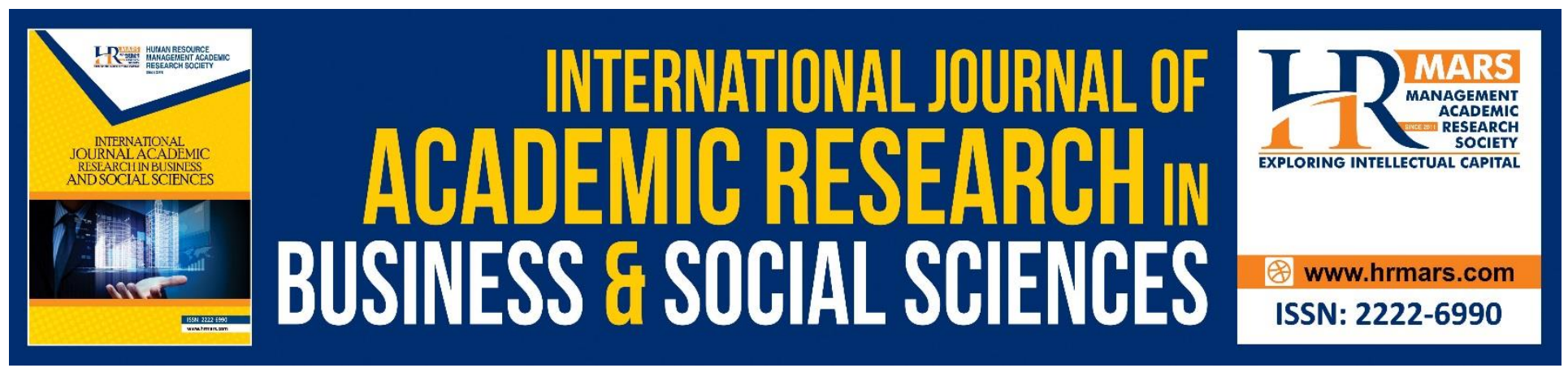

\title{
Can Bio-labels help Companies to Gain Competitive Advantage in the Organic Food Market in Germany?
}

\author{
Dr. Federico, G. Topolansky Barbe, Franz-Georg, Wolfhard, Magdalena, M. \\ Gonzalez Triay
}

To Link this Article: http://dx.doi.org/10.6007/IJARBSS/v8-i8/4468

DOI: $\quad 10.6007 /$ IJARBSS/v8-i8/4468

Received: 18 July 2018, Revised: 13 August 2018, Accepted: 27 August 2018

Published Online: 30 August 2018

In-Text Citation: (Federico, Franz-Georg, \& Magdalena, 2018)

To Cite this Article: Federico, G. T. B., Franz-Georg, W., \& Magdalena, M. G. T. (2018). Can Bio-labels help Companies to Gain Competitive Advantage in the Organic Food Market in Germany? International Journal of Academic Research in Business and Social Sciences, 8(8), 264-278.

Copyright: (C) 2018 The Author(s)

Published by Human Resource Management Academic Research Society (www.hrmars.com)

This article is published under the Creative Commons Attribution (CC BY 4.0) license. Anyone may reproduce, distribute, translate and create derivative works of this article (for both commercial and non-commercial purposes), subject to full attribution to the original publication and authors. The full terms of this license may be seen

at: http://creativecommons.org/licences/by/4.0/legalcode

Vol. 8, No. 8, August 2018, Pg. 264 - 278

http://hrmars.com/index.php/pages/detail/IJARBSS

JOURNAL HOMEPAGE

Full Terms \& Conditions of access and use can be found at http://hrmars.com/index.php/pages/detail/publication-ethics 


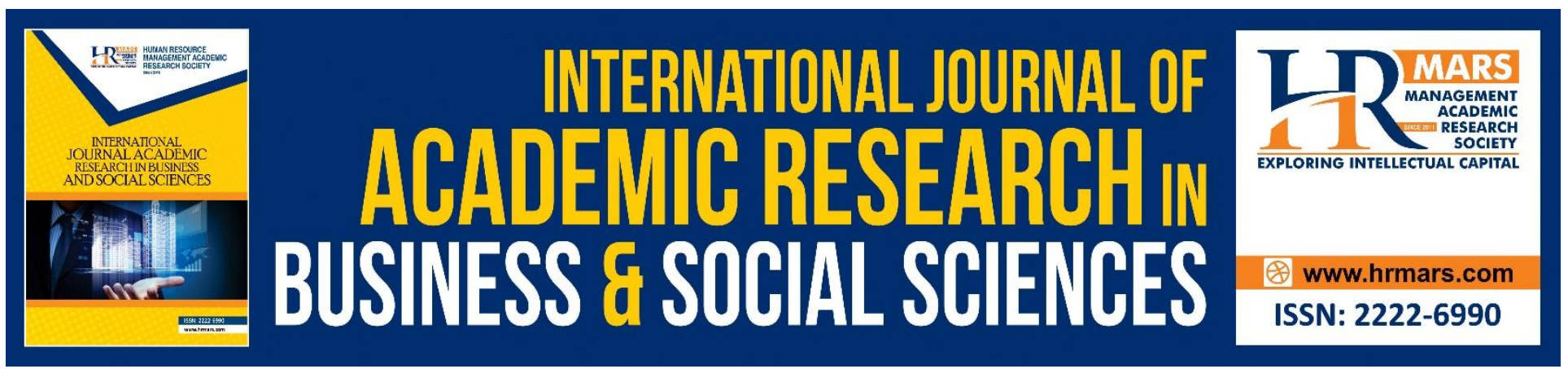

\title{
Can Bio-labels help Companies to Gain Competitive Advantage in the Organic Food Market in Germany?
}

\author{
Dr. Federico, G. Topolansky Barbe \\ The Royal Agricultural University, School of Business and Entrepreneurship, GL7 6JS, United Kingdom
}

Franz-Georg, Wolfhard

The Royal Agricultural University, School of Business and Entrepreneurship, GL7 6JS, United Kingdom

Magdalena, M. Gonzalez Triay

University of Gloucestershire, School of Business, GL5O 2RH, United Kingdom

\begin{abstract}
Consumers' attitudes towards food underwent large changes in Germany. This has resulted in an increase of demand for organic food. However, some analysts claim that the organic food market in Germany might be maturing. Within this context, this paper has two main objectives: first, to explore the attitude of German consumers towards organic food and bio-labels; and second to identify potential areas for improvement to help organic food companies to become more competitive. This study used a quantitative research approach. 627 German consumers completed the survey. The results of this study indicate that there is potential for the organic food market to carry on growing. Findings have also revealed that a large percentage of participants do not trust some bio-labels. Trust and brand recognition are the most important factors that have helped Bioland and Demeter to develop a competitive advantage against other labels.
\end{abstract}

Keywords: Competitiveness, Organic Food, Bio-Labels, Germany, Quantitative Research Approach

\section{Introduction}

Agricultural industrialization in Western Europe has helped to meet food demand for a growing population. However, this intensive way of production has had devastated consequences for our planet (Cronin et al. 2011). Consumers' concerns over unsustainable ways of production and food security has prompted many food producers to look at more environmentally friendly ways of production (Hahn and Scheermesser 2006).

A change in consumer behavior resulted in a substantial increase in demand for organic produce in Germany. Many farmers have decided to convert to organic farming to capitalize on this growing 
market looking for sustainable healthy diets (Cronin et al. 2011). A large number of these farmers have adopted the minimum standards set by the EU-Bio-Regulation. Private organic labels have adopted their own standards, many of which are more demanding than the ones set by the EU-BioLabel. In theory, these labels help consumers to identify those products produced to the highest quality standards. However, they can also lead to confusion as there are numerous labels with a wide range of different demands regarding production and processing (Thøgersen et al. 2010).

Inevitably, the growth of the organic sector in Germany will slow down and move to the mature stage of the industry life cycle. This will increase competition making difficult for incumbent firms to maintain their market position or increase market share. Good companies need to adjust their strategies in line with the different stages of the industry life cycle. Within this context, companies must understand how organic foods are perceived and which sectors have the highest potential for growth. A good understanding of consumers' perceptions and attitudes towards organic food and changes in the external environment will help companies to develop successful strategies (Grant 2010).

An understanding of consumers' attitude towards organic food will help companies to adjust their product range and to develop more appealing new products. In doing this, companies need to be aware of the role played by eco-labels. Germany is the country with the largest number of eco-labels in Europe. However, German consumers have expressed their discontent and mistrust with the different standards and amount of information presented by some of these eco-labels (Visschers et al. 2009).

The specific objectives of this study are as follows: first, to better understand German consumers' attitudes and behaviours toward organic food; and second, to identify areas of improvement to help incumbent and newcomers to develop sustainable strategies.

\section{Organic Farming and Bio-Labels}

The idea of organic farming first rose in the era of postmodernism, between the two world wars. During that time, agriculture was in a difficult position, facing problems of soil fatigue, soil consolidation, loss of seeding material, pest infestations, and plant diseases. The natural farming model was created as an alternative to tackle the problems of industrial agriculture. The idea behind it was to adopt more sustainable ways of production. It was based on the so called "agricultural bacteriology", which concentrated on the importance of soil fertility (Eames 2016).

There is no universal definition for organic agriculture, it varies between countries and organizations. However, the universal goal of organic farming is to achieve a closed cycle of production and energy within the farm (Diercks 1983). Over the last years, organic agriculture has been growing consistently all over the world. Today, organic foods are produced in more than 170 countries. However, only 82 countries have and own biological laws (Bund ökologischer Lebensmittelwirtschaft 2015). In Germany, the German Ministry of Agriculture and Food states all the regulations that organic producers must comply with (Bundesamt für Landwirtschaft und Ernährung 2013).

Organic foods are perceived by many consumers as environmentally friendly, healthy and having high ethical and welfare standards. An increased demand for organic food has prompted even discount retailers to offer organic foods (Stolz et al. 2010). Aldi, Edeka and Rewe have become the major players influencing the pricing and variety of organic produce in Germany (AMI 2014). Despite growing demand for organic food from socially conscious consumers, organic food remains a niche market. For example, organic farmland still accounts for less than two percent of the entire land used for agricultural purposes (Willer and Kilcher 2014). 
INTERNATIONAL JOURNAL OF ACADEMIC RESEARCH IN BUSINESS AND SOCIAL SCIENCES Vol. 8, No. 8, August 2018, E-ISSN: 2222-6990 @ 2018 HRMARS

The following factors are responsible for the increase of organic production in Germany:

- Increasing demand for ecological grown food;

- Subsidies received by The European Union and the German Republic;

- High market prices for organic foods (Oekolandbau 2015).

Germany is the largest market for organic foods in Europe (Statista 2015). Despite the steady growth over the last decade, the growth stagnated from 2013.This was mainly due to a reduced price difference between ecological and conventional food products, making ecological farming less lucrative. In addition, cheap imports from foreign markets, have made the German market less attractive for incumbent firms. Furthermore, leasing of agricultural land has become more and more expensive due to state support for the usage of biogas plants. The state subsidized biogas plants for 20 years making farmland unaffordable for ecological agriculture (Umweltbundesamt 2015).

In the organic agriculture and food sector, the terms eco and bio are used as synonyms (Oekolandbau 2015). In Germany, those products that carry an eco-code or the EU-bio-label are considered bioproducts (Organicstyle 2010).

As Germany is a member of the European Union, it underlies the Common Agricultural Policy (CAP), which includes the common framework for commercial policy and import. The "Council Regulation (EEC) No. 834/2007 of 28 June 2007 on organic production and labelling of organic products defines how products and foods, which are labelled as biological goods have to be labelled, grown and produced. The regulation is linked to the principles of the International Federation of Organic Agriculture Movements (IFOAM), in which 750 organizations from 108 countries are organized (Council Regulation 2007).

There are two governmental labels. The EU-bio-label, run by the European Union standards and the German Bio-Siegel, which was developed specifically for the German market (Oekolandbau 2016). The Bio-Siegel was introduced in 2011 with the aim of making it easier for the consumer to recognize bio- foods. It can be used in addition to the EU-Bio-Label on a voluntary basis (BMEL 2015).

Over the years, organic farming associations have developed their own labels to promote their own organic standards and idea of farming. Their standards are often stricter than the EU standards. Members of such associations can use their label to advertise their products. The most important associations for the German market in terms of size and profile are: Bioland, Der Blaue Engel, Demeter, Naturland and Biokreis (Demeter 2014; BMEL 2015).

\section{Consumer Behavior}

The consumer attitude and behavior play a major role in the marketing of organic food (Kuester 2012). Consumer behavior is driven by a number of external and internal factors. Internal influences can be sub classified into personal and psychological factors and external influences can be sub classified into cultural and social factors (Armstrong and Kotler 2007).

Some studies suggest that demand for organic food is positively correlated to income (Davies et al. 1995; Wier and Calverley 2002). It is also recognized that people with a high organic food consumption are most often found in cities that tend to rank high in income, education and occupation (Zanoli et al. 2004). Also, there is a direct link between a person's education and the frequency of organic food he purchases (Padel and Foster 2005).

There is a different level of environmental awareness and the urge for a healthy lifestyle between different age levels. This influences the purchasing behavior of organic foods (Fotopoulos and Krystallis 2002). Young consumers with high income tend to be the largest consumers of organic food (Padel and Foster 2005). 
There are various motives for consumers to choose organic food. In comparison to conventional farming, organic farming has a number of beneficial impacts on the environment such as increased biodiversity, lower input of pesticide and a healthier soil structure (Lohr 2005). As today's environment is increasingly at risk, a more environmentally friendly way of farming becomes important for some consumers (Gracia and De Magistris 2008).

With health issues taking a center stage for today's society, organic food is seen as one of the solutions for a healthy lifestyle. This along with an increased awareness for animal rights have led to an increase of consumption of certain types of organic food (Padel and Foster 2005). Taste and quality have also been identified as important drivers for organic consumption. Even though there is no scientific evidence suggesting that organic food taste better, some consumers by organic because they perceive a difference in quality and taste (Zanoli et al. 2004).

Food scandals have been identified as another factor influencing positively on the consumption of organic food. Trust on a food product affects the decision making process. Bio-labels play an important role in providing relevant information such as the origin of food, traceability, animal welfare, etc. The "local food" trend is often associated with the support of the local organic farming community, as well as taking a stand against multinational food companies (Zanoli et al. 2004).

According to several authors there are several barriers that have prevented a further development of the organic sector. The most important ones being: lack of availability, the premium price and appearance (Robles et al. 2005).

\section{Methodology}

A positivist, deductive research approach was deemed the most appropriate approach to address the objectives of this research. A survey method was selected to collect primary data from German consumers. The questionnaire consisted of 32 questions. Respondents were informed that anonymity would be preserved and that the questionnaire should take around 20 minutes to complete. Information regarding the time to finish the questionnaire was given to avoid losing motivation due to uncertainty regarding remaining time to complete the questionnaire. Prior to data collection, the questionnaire was pre-tested (using a pilot test) on a total of four additional participants and some corrections were made regarding the use of language and the questioning style.

As the questionnaire was directed to people living and shopping in Germany, the questionnaire was designed in the German language. This survey used closed-ended questions. It was decided to opt for this type of questions due to the objectivity and higher comparability of this type of method (Bortz and Döring 2006). The questionnaire was subdivided in three parts. The first part gathered background information about the respondents. The second part looked at the participants' attitudes and behavior towards organic foods. The final part of the questionnaire collected data to assess participants' perceptions and understanding of organic-labels.

The given questions used Likert scale questions and multiple and single choice questions. Respondents were asked to rank their beliefs, attitudes and opinions against a five-point Likert scale. The questionnaire was put online over a period of three months and a total of 627 questionnaires were completed. The collected data was analysed using Microsoft excel. This data analysis tool is suited to the aims of this study which aimed to better understand German consumers' attitudes and behaviours toward organic food; and to identify areas of improvement to help incumbent and newcomers to develop sustainable strategies. 
INTERNATIONAL JOURNAL OF ACADEMIC RESEARCH IN BUSINESS AND SOCIAL SCIENCES Vol. 8, No. 8, August 2018, E-ISSN: 2222-6990 @ 2018 HRMARS

\section{Research Findings}

Tables 1, 2, 3, 4 and 5 provide some demographic information on the study participants.

Table 1: Gender of the study participants

\begin{tabular}{|l|l|l|}
\hline Gender & $\mathbf{n}$ & \% \\
\hline Female & 283 & 45.10 \\
\hline Male & 344 & 54.90 \\
\hline
\end{tabular}

Table 2: Age range of the study participants

\begin{tabular}{|l|l|l|}
\hline Age range (years) & $\mathbf{n}$ & \% \\
\hline $18-25$ & 120 & 19.10 \\
\hline $25-35$ & 144 & 22.90 \\
\hline $36-45$ & 167 & 26.60 \\
\hline $46-60$ & 153 & 24.40 \\
\hline Over 60 & 43 & 7.10 \\
\hline
\end{tabular}

Table 3: Family status

\begin{tabular}{|l|l|l|}
\hline Family status & $\mathbf{n}$ & \% \\
\hline Single & 277 & 44.10 \\
\hline In a relationship & 129 & 20.60 \\
\hline Married & 184 & 29.40 \\
\hline Widowed & 9 & 1.50 \\
\hline Divorced & 28 & 4.40 \\
\hline
\end{tabular}

Table 4: Households with children under 18 years old

\begin{tabular}{|l|l|l|}
\hline Children below 18 years old & $\mathbf{n}$ & \% \\
\hline Yes & 147 & 23.40 \\
\hline No & 480 & 76.60 \\
\hline
\end{tabular}

Table 5: Per month disposable income

\begin{tabular}{|l|l|l|}
\hline Disposable income & $\mathbf{n}$ & \% \\
\hline Below $900 €$ & 79 & 12.70 \\
\hline $900-1500 €$ & 97 & 15.50 \\
\hline $1500-2000 €$ & 192 & 30.60 \\
\hline $2500-3500 €$ & 135 & 21.50 \\
\hline Over $3500 €$ & 124 & 19.70 \\
\hline
\end{tabular}

Respondents were asked about how often they buy organic food. 
INTERNATIONAL JOURNAL OF ACADEMIC RESEARCH IN BUSINESS AND SOCIAL SCIENCES Vol. 8, No. 8, August 2018, E-ISSN: 2222-6990 @ 2018 HRMARS

Figure 2. Frequency of organic food purchases

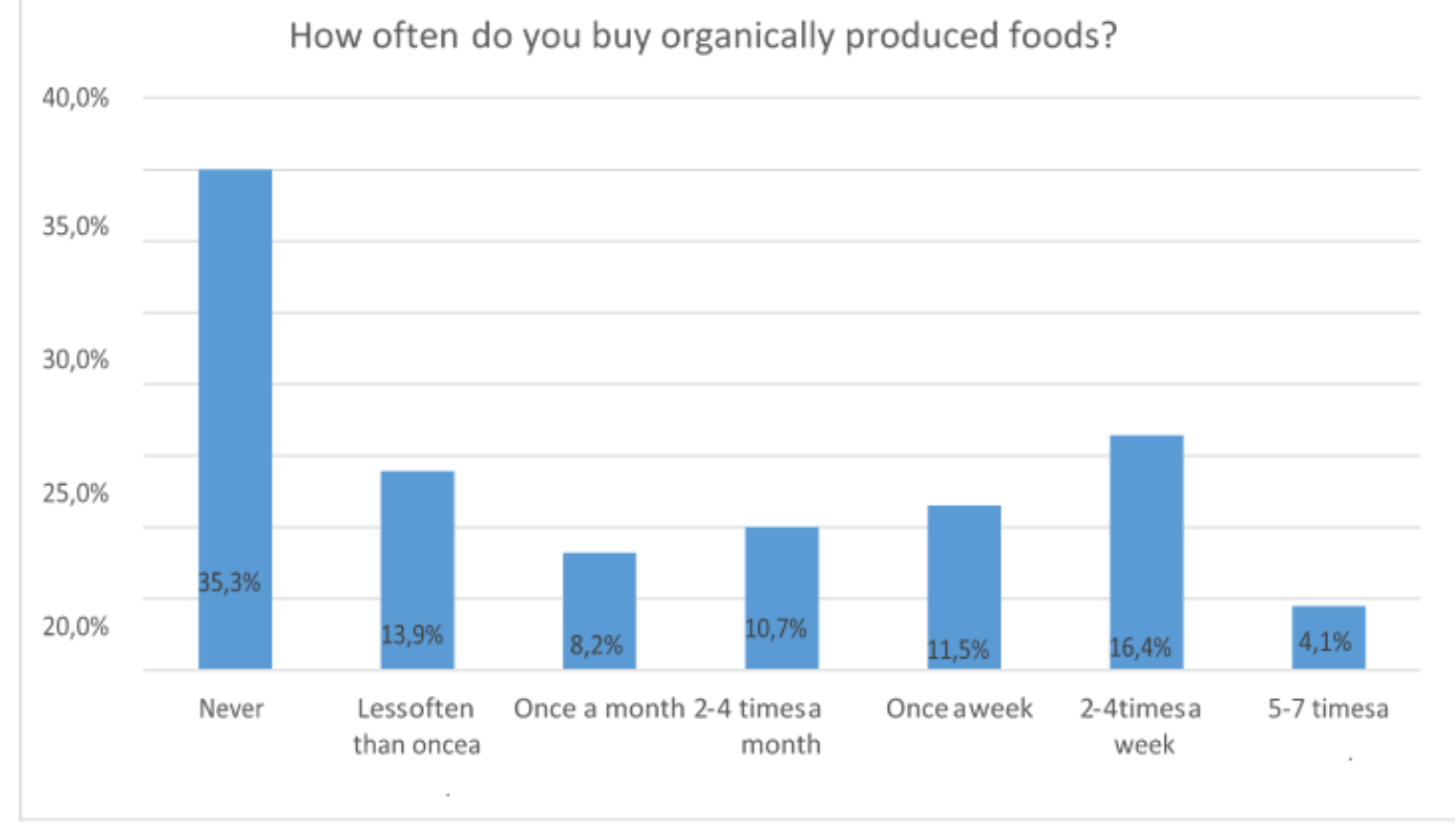

The results show that almost half of respondents never or hardly ever buy organic food. Among the $51 \%$ that buys organic food only four percent buy organic food on a daily basis.

Figure 3. Most frequently used facilities for organic foods

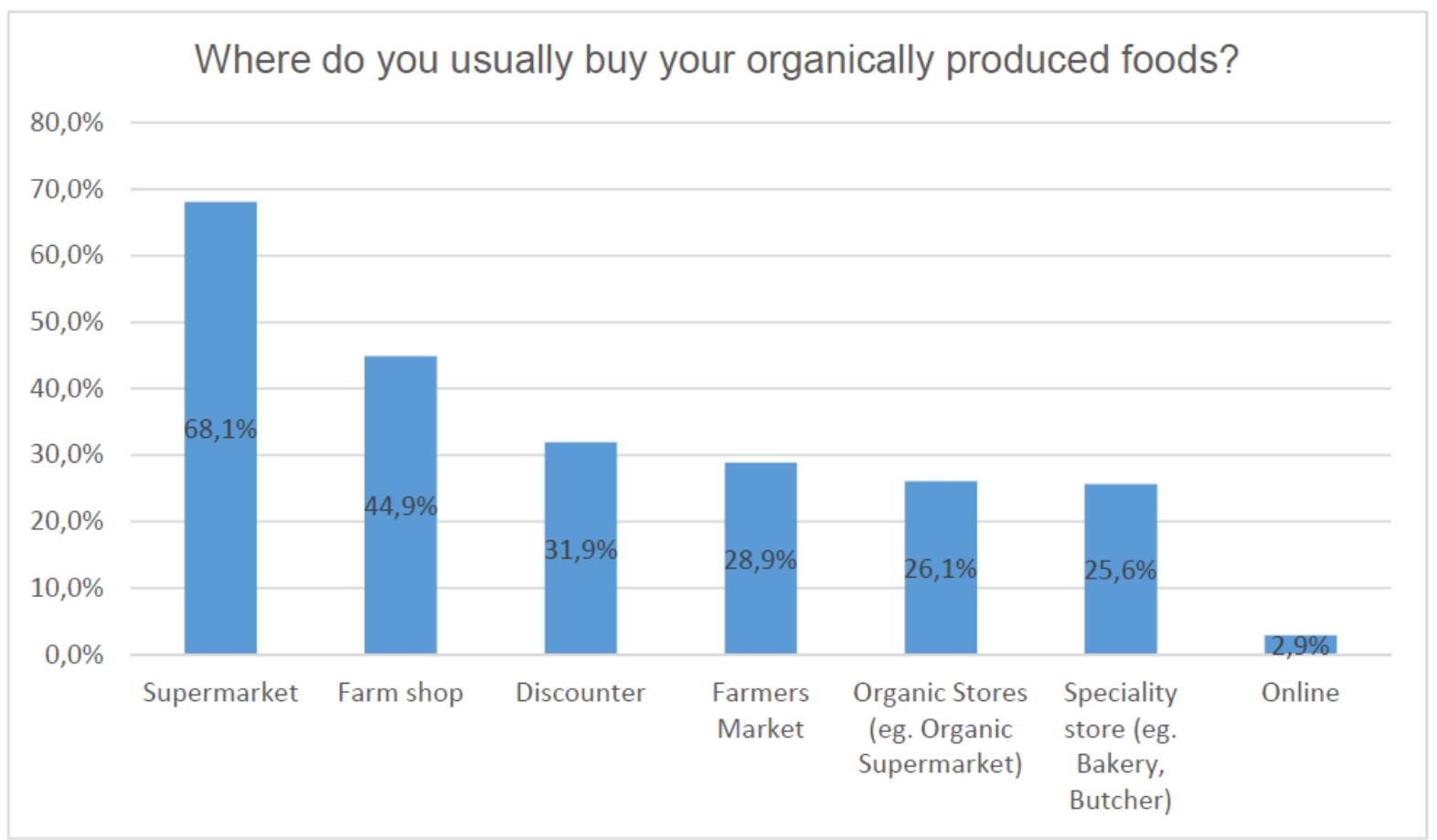

Most of the respondents (68\%) mentioned that they purchase organic food at supermarkets. Farm shops come second being used by $45 \%$ of targeted consumers. The rest of the facilities range between $26 \%$ and $32 \%$. Surprisingly, less than $3 \%$ of respondents buy organic food online. 
INTERNATIONAL JOURNAL OF ACADEMIC RESEARCH IN BUSINESS AND SOCIAL SCIENCES Vol. 8, No. 8, August 2018, E-ISSN: 2222-6990 @ 2018 HRMARS

Even though the majority of respondents purchase organic food at supermarkets, these stores are the least trusted. Only $13 \%$ of respondents trust supermarkets. Farm shops (62\%) and speciality stores (42\%) are the most trusted places to buy organic food.

Respondents were asked to express their opinion about the most important aspects when buying organic food. The majority of respondents (66\%) stated that the origin of the product is the most important factor. Price (36\%) and appearance (35\%) are the other two most important factors during the decision making process. Interestingly, only $18 \%$ of respondents pay attention to the EU-bio-label.

Figure 4. Issues paid attention to when buying organic foods

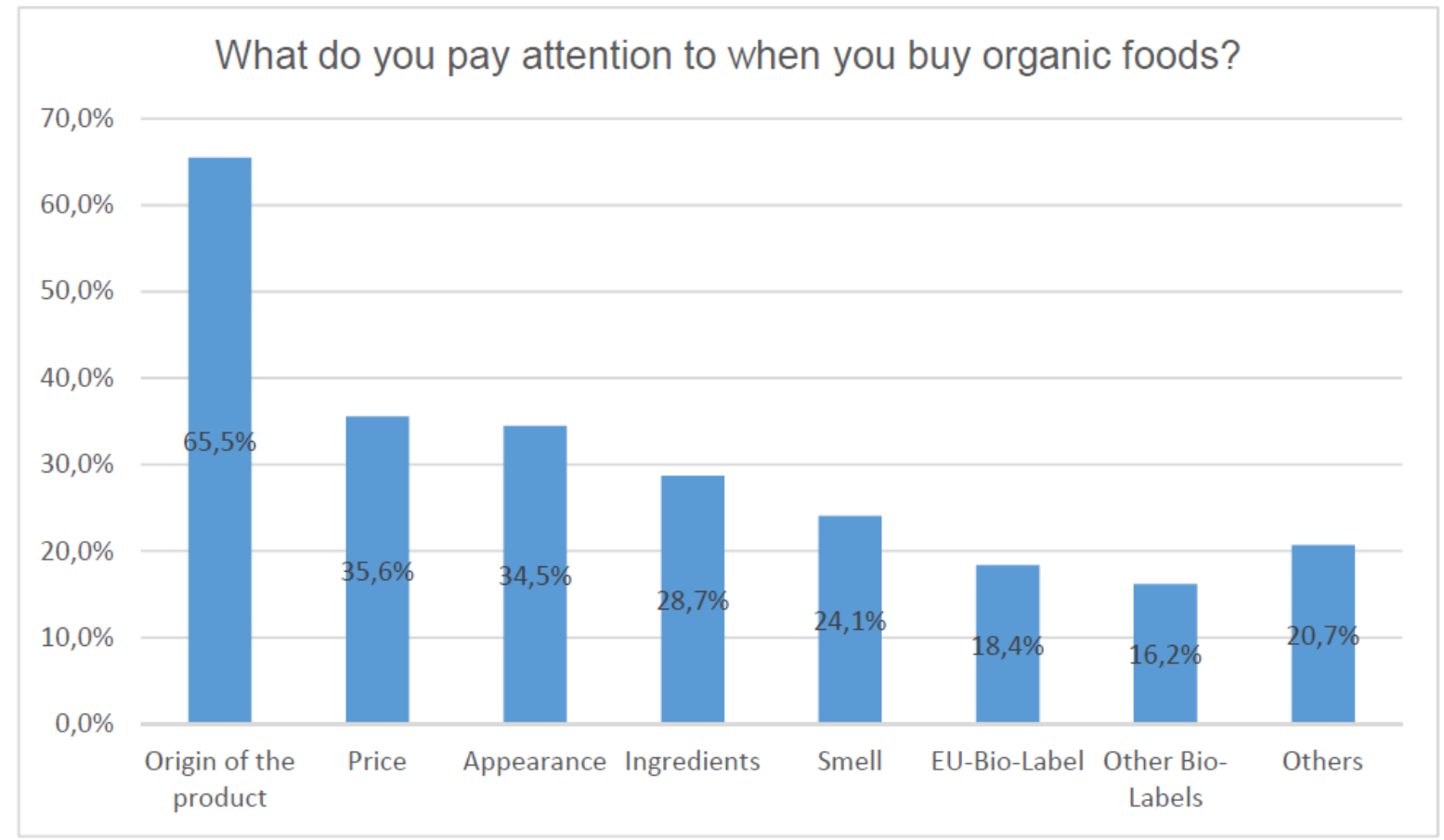

A likert scale was used to understand which aspects targeted consumers' link with organic produced food. Results indicate that respondents have varied opinions in relation to some aspects. While $23 \%$ of respondents agreed that organically produced foods have a higher nutritional value than conventional food products, $60 \%$ disagree or strongly disagree with this idea.

More consensus was found when participants were asked about the environmental credentials of organic food. $49 \%$ of respondents believe that organic food is environmentally friendly produced. Similarly, $50 \%$ of participants stated that organic products are healthy, $49 \%$ that are free of pesticides, $55 \%$ that are free of GMO's and 50\% that are free of chemical fertilizers. Also, $43 \%$ of participants believe that organic food is locally produced. 
INTERNATIONAL JOURNAL OF ACADEMIC RESEARCH IN BUSINESS AND SOCIAL SCIENCES Vol. 8, No. 8, August 2018, E-ISSN: 2222-6990 @ 2018 HRMARS

Figure 5. Aspects linked with organically produced food

\begin{tabular}{|c|c|c|c|c|c|}
\hline & $\begin{array}{l}\text { Strongly } \\
\text { agree }\end{array}$ & Agree & Neutral & Disagree & $\begin{array}{l}\text { Strongly } \\
\text { disagree }\end{array}$ \\
\hline $\begin{array}{l}\text { Higher } \\
\text { nutritional } \\
\text { value than } \\
\text { conventional } \\
\text { food products }\end{array}$ & $11,1 \%$ & $12,2 \%$ & $16,7 \%$ & $17,8 \%$ & $42,2 \%$ \\
\hline $\begin{array}{l}\text { Environmentally } \\
\text { friendly } \\
\text { produced }\end{array}$ & $19,8 \%$ & $28,6 \%$ & $20,9 \%$ & $9,9 \%$ & $20,9 \%$ \\
\hline Healthy food & $26,9 \%$ & $22,5 \%$ & $19,1 \%$ & $11,2 \%$ & $20,2 \%$ \\
\hline $\begin{array}{l}\text { Free of } \\
\text { pesticides }\end{array}$ & $21,1 \%$ & $27,8 \%$ & $20,0 \%$ & $15,4 \%$ & $15,9 \%$ \\
\hline $\begin{array}{l}\text { Free of chemical } \\
\text { fertilizers }\end{array}$ & $22,7 \%$ & $27,3 \%$ & $21,6 \%$ & $11,4 \%$ & $17,1 \%$ \\
\hline $\begin{array}{l}\text { Locally } \\
\text { produced }\end{array}$ & $21,1 \%$ & $22,2 \%$ & $16,7 \%$ & $17,8 \%$ & $22,2 \%$ \\
\hline Free of GMO`s & $26,7 \%$ & $27,8 \%$ & $23,3 \%$ & $6,7 \%$ & $15,6 \%$ \\
\hline Fair trade & $7,8 \%$ & $24,4 \%$ & $21,1 \%$ & $14,4 \%$ & $32,2 \%$ \\
\hline
\end{tabular}

To further understand consumers' attitudes towards organic food, participants were asked the reasons for buying this type of food. Findings suggest that the largest reason for participants to buy organically produced foods is to support the local agriculture (44\%), followed by the belief that they are free of pesticides (39\%) and the idea that they are environmentally friendly produced (36\%). The belief that they are free of chemical fertilizers and GMO's both account for 35\% of participants' reasons for purchasing organic products. Health issues (30\%), taste (28\%), to safe resources (26\%) and to support animal welfare (25\%) are also of importance as a purchasing driver. Fair trade (15\%) and a higher nutritional value (11\%) are of lesser importance, while image reasons (5\%) are of least importance to the targeted consumers. 
INTERNATIONAL JOURNAL OF ACADEMIC RESEARCH IN BUSINESS AND SOCIAL SCIENCES

Vol. 8, No. 8, August 2018, E-ISSN: 2222-6990 C 2018 HRMARS

Figure 6. Reasons for buying organically produced food

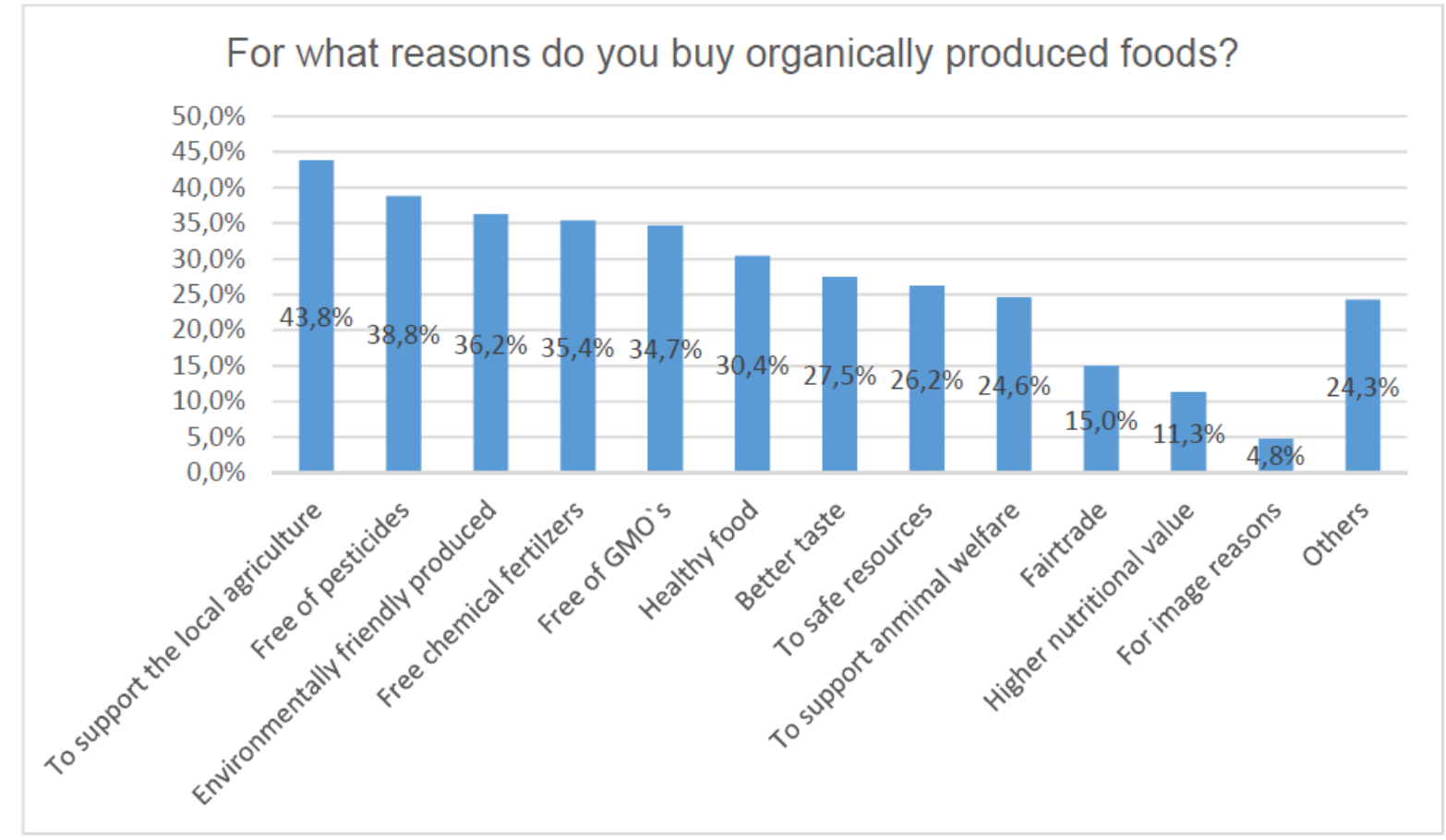

The research also explored those factors that would make respondents to purchase organic food more regularly. Findings indicate that price $(42 \%)$ is the most important factor preventing participants to consume more organic food. Product availability $(27 \%)$ and product range $(23 \%)$ are the other two important factors.

Primary data revealed that vegetables (53\%), eggs (47\%) and meat (45\%) are the organic foods consumed more regularly by those consumers targeted in this study. Many respondents stated that, in the future, they would like to consume more organic fish.

The second part of the questionnaire aimed at unveiling the participants' attitude towards bio-labels and how they influence their purchasing behavior. 
INTERNATIONAL JOURNAL OF ACADEMIC RESEARCH IN BUSINESS AND SOCIAL SCIENCES Vol. 8, No. 8, August 2018, E-ISSN: 2222-6990 @ 2018 HRMARS

Figure 7. General attitude towards bio-labels

\begin{tabular}{|c|c|c|c|c|c|}
\hline & $\begin{array}{l}\text { Strongly } \\
\text { agree }\end{array}$ & Agree & Neutral & Disagree & $\begin{array}{l}\text { Strongly } \\
\text { disagree }\end{array}$ \\
\hline $\begin{array}{l}\text { I'm well } \\
\text { informed about } \\
\text { bio-labels }\end{array}$ & $15,1 \%$ & $30,2 \%$ & $19,8 \%$ & $20,9 \%$ & $13,9 \%$ \\
\hline $\begin{array}{l}\text { Bio-labels on } \\
\text { foods are } \\
\text { important to } \\
\text { me }\end{array}$ & $7,1 \%$ & $20,2 \%$ & $17,9 \%$ & $19,1 \%$ & $35,7 \%$ \\
\hline $\begin{array}{l}\text { Bio-labels } \\
\text { influence my } \\
\text { purchasing } \\
\text { decisions }\end{array}$ & $8,4 \%$ & $25,3 \%$ & $19,3 \%$ & $15,7 \%$ & $31,3 \%$ \\
\hline $\begin{array}{l}\text { I have trust in } \\
\text { bio-labels on } \\
\text { foods }\end{array}$ & $3,5 \%$ & $15,3 \%$ & $22,4 \%$ & $14,1 \%$ & $44,7 \%$ \\
\hline
\end{tabular}

The above figure suggests that many respondents (45\%) agree or strongly agree with the statement that they are well informed about bio-labels. 34\% of the participants agree or strongly disagree with the statement that bio-labels influence their purchasing decision. Interestingly, only $19 \%$ of targeted consumers stated that they have trust in bio-labels.

Figure 8. Influence of bio-labels on consumer behaviour

\begin{tabular}{|c|c|c|c|c|c|}
\hline & $\begin{array}{l}\text { Strongly } \\
\text { agree }\end{array}$ & Agree & Neutral & Disagree & $\begin{array}{l}\text { Strongly } \\
\text { disagree }\end{array}$ \\
\hline $\begin{array}{l}\text { Foods with a } \\
\text { bio-label are of } \\
\text { higher quality } \\
\text { than } \\
\text { others }\end{array}$ & $8,6 \%$ & $17,3 \%$ & $25,9 \%$ & $13,6 \%$ & $34,6 \%$ \\
\hline $\begin{array}{l}\text { Foods with a } \\
\text { bio-label draw } \\
\text { more } \\
\text { attention } \\
\text { than others } \\
\end{array}$ & $5,0 \%$ & $33,8 \%$ & $23,7 \%$ & $16,3 \%$ & $21,3 \%$ \\
\hline $\begin{array}{l}\text { At comparable } \\
\text { prices, l'd buy } \\
\text { a product with } \\
\text { a bio-label } \\
\text { over others }\end{array}$ & $22,2 \%$ & $17,3 \%$ & $19,8 \%$ & $8,6 \%$ & $32,1 \%$ \\
\hline $\begin{array}{l}\text { When buying } \\
\text { food, } \\
\text { specifically look } \\
\text { out for } \\
\text { bio-labels }\end{array}$ & $8,9 \%$ & $13,9 \%$ & $14,9 \%$ & $17,7 \%$ & $44,6 \%$ \\
\hline
\end{tabular}


INTERNATIONAL JOURNAL OF ACADEMIC RESEARCH IN BUSINESS AND SOCIAL SCIENCES Vol. 8, No. 8, August 2018, E-ISSN: 2222-6990 @ 2018 HRMARS

In spite of $55 \%$ of participants claiming that they do not trust bio-labels, $40 \%$ of them alleged that at comparable prices they would purchase a product with bio-label over others without a label. In addition, 39\% of respondents agree or strongly agree that bio-labels draw more attention that products without labels. Respondents expressed mixed views on the quality of food with bio-labels. While $26 \%$ of them agree or strongly agree that foods with bio-labels are of higher quality, $48 \%$ of them disagree or strongly disagree with the statement.

This research looked at the recognition of the main bio-labels. Among them, the Bioland label has the highest recognition with $81 \%$ of participants knowing it. Demeter (66\%) and the EU-bio-label (58\%) are also known by an over proportional percentage of people. The Naturland label is known by roughly every second participant (51\%) and the Biokreis label was only recognized by $17 \%$ of respondents.

Part of the questionnaire was designed to reveal participants' perceptions on the main labels. Several participants agree with the statement that foods with a EU- bio-label are biological produced (38\%) and free of GMO`s (35\%). Another 35\% agree with the statement that the goods are controlled on a regular basis. That they carry few additives and contain little contamination by harmful substances is agreed on by $21 \%$ and $22 \%$ respectively. $18 \%$ agree with the statement that EU-bio-labelled goods are fully traceable. The lowest agreement, with just $7 \%$ is received by the statement that it is produced in Germany.

In the case of the Demeter-label 55\% of participants believe their products are biologically produced and $49 \%$ that are free of GMO's and controlled on regular basis. $31 \%$ agree that they have little contamination by harmful substances and $29 \%$ state that they are regional produced. Consumers' perceptions about Bioland-label are very similar. The only difference being that $34 \%$ of participants believe that foods that carry the Bioland-label are produced in Germany.

$44 \%$ percent of respondents agree with the statement that Naturland- labelled foods are biological produced (44\%), contain little contamination (26\%) and controlled on a regular basis. A similar proportion (41\%) agrees that Naturland products are GMO free. 35\% agree that Naturland-labelled products have few additives and $29 \%$ believe that they are produced in Germany.

This study revealed very different perceptions regarding the Biokreis-label. Only $25 \%$ of the participants agree that Biokreis-labelled products are biological produced and are GMO free. 20\% agree that Biokreis products are controlled on a regular basis and $19 \%$ believe they carry few additives. $15 \%$ of participants believe that these products are regionally produced.

Respondents were asked about their trust on Bio-labels. Results indicate that respondents rank Biolabels by trust as follows:

1. Bioland

2. Demeter

3. Naturland

4. EU-Bio label

5. Biokreis

Not surprisingly, the results indicate that $35 \%$ of participants looked for the Bioland label when purchasing organic food and only $13 \%$ considered the Biokreis label. The research also indicates that at comparable prices, $46 \%$ of the participants agree, or strongly agree that they would buy a product with a Bioland label, over a product without a label. 
INTERNATIONAL JOURNAL OF ACADEMIC RESEARCH IN BUSINESS AND SOCIAL SCIENCES

Vol. 8, No. 8, August 2018, E-ISSN: 2222-6990 @ 2018 HRMARS

\section{Discussion}

This study has revealed that the majority of respondents have purchased organic food at some point in their life. Among them, 33\% tend to purchase organic food less than once a week. Here there is a marketing opportunity to try to convert this group of consumers onto regular buyers.

In line with previous research, collected data suggests that most participants purchase organic food at supermarkets (60\%). Interestingly, this study has also revealed that farm shops are the second most popular retail outlet for buying organic food. Although farm shops are seen as the most trusted places to buy organic food, several consumers (33\%) state that, in the future, they would like to buy more organic food from supermarkets and discounters. This might be due to the convenience of buying everything in one shop. An expansion of the organic offer in supermarkets and discounters could increase the sales. Also, the image problem of organic foods from discounters and supermarkets needs to be addressed. At the same time, the survey shows that there is high trust in farm shops, specialty stores and farmer's markets. If these shopping facilities use the given trust well and set themselves up at the right, more convenient locations they could also increase their sales and establish themselves as a permanent alternative to supermarkets and discounters. With only $3 \%$ of targeted consumers buying organic food online there is an opportunity for marketers to concentrate on this popular sales channel for younger and open minded generations.

The analysis of data has revealed that the origin of food, an environmentally friendly way of production, and healthy food were the most important factors influencing the decision making process of the German consumers' targeted by this study. Marketers through educational advertisement should inform potential consumers about the personal and environmental benefits of organic over conventional food. This strategy could help the organic food sector to increase sales and to reach new segments.

Price, availability, appearance and diversity of organic food were identified as the main barriers preventing consumers to consume more organic food. Addressing some of these aspects will help to further grow a market that might be experiencing some signs of maturity. An efficient management of the food supply chain might allow improving the availability and diversity of organic food. For this to happen, communication among all stakeholders within the supply chain needs improvement. This is not an easy task due to the different size, power and number of stakeholders that integrate the food supply chain.

When it comes to product preferences the results of his study were very similar to the results of other studies conducted in Germany in 2014 (Bund ökologischer Lebensmittelwirtschaft, 2015). However, the analysis of data also revealed that fish was the product most participants would like to purchase in the future. This provides an opportunity for future growth. As Germany has, in comparison to its size, a relatively short coastline the local market would not benefit so much from organic fish farms for salt-water fish. For fresh-water fish on the other hand, it would be easier to supply the market with organic fish from Germany.

When asked about bio-labels the results indicate that most recognized labels (Bioland and Demeter) are perceived by consumers as having better quality, being more environmentally friendly and being heathier than less recognized labels. Still there is some level of mistrust with regards to the process followed by eco labels in general but mainly towards programs being managed by the European Union. Marketers will have to identify where this mistrust comes from in order to best tackle this issue which clearly is preventing the sector from further growing.

The combination of the high recognition and the positive attitude linked to Bioland and Demeter, make these labels a good marketing tool for farmers that are part of one of those associations and 
INTERNATIONAL JOURNAL OF ACADEMIC RESEARCH IN BUSINESS AND SOCIAL SCIENCES Vol. 8, No. 8, August 2018, E-ISSN: 2222-6990 @ 2018 HRMARS

farm by their standards. This should also be of interest for other organic farmers that try to increase their business opportunities and those that consider to start organic farming. Being part of one of those associations and using their labels could give them a valuable advantage over competitors on the market.

\section{Corresponding Author}

Dr. Federico, G. Topolansky Barbe

The Royal Agricultural University,

School of Business and Entrepreneurship,

GL7 6JS, United Kingdom

Email: federico.topolansky@rau.ac.uk \& agrotopo@hotmail.com

\section{References}

AMI. (2014). Organic market in Germany 2014. Retrieved October 3 $3^{\text {rd }}$ 2017, from: http://orgprints.org/28229/7/schaack-2015-02-12-OrganicMarketGermany.pdf

Armstrong, G. \& Kotler, P. (2007). Marketing: an introduction. Pearson Prentice Hall, New Jersey. BMEL. (2015) . Bio-Siegel. Retrieved December 14 ${ }^{\text {th }}, 2017$, from:

http://www.bmel.de/DE/Landwirtschaft/Nachhaltige-Landnutzung/Oekolandbau/ Texte/Bio-

Siegel.html

Bortz, J. \& Döring, N. (2006). Forschungsmethoden und Evaluation für Human- und Sozialwissenschaftler. Heidelberg: Springe

Bund ökologischer Lebensmittelwirtschaft. (2015). BÖLW-, BNN-, AMI-, FIBL- und IFOAM-

Bilanzpressekonferenz. Retrieved January $9^{\text {th }}, 2018$, from:

https://www.boelw.de/fileadmin/media/pdf/Themen/Branchenentwicklung/ZDF 2016/BOELW ZD

F 2016 web.pdf

Bundesanstalt für Landwirtschaft und Ernährung. (2013). Auf einen Blick: Informationen zum Bio-

Siegel (vom Bundesministerium für Ernährung, Landwirtschaft und Verbraucherschutz). Retrieved

September $14^{\text {th }}, 2017$, from: http://www.bio-siegel.de/infos-fuer-verbraucher/das-staatliche-bio-

siegel/

Council Regulation. (2007). Verordnung (EG) Nr. 834/2007 des Rates. Retrieved February $1^{\text {st }}, 2017$

https://eur-lex.europa.eu/legal-content/DE/TXT/?uri=celex\%3A32007R0834

Cronin, J. J., Smith, J. S., Gleim, M. R., Ramirez, E. \& Martinez, J. D. (2011). Green marketing strategies:

an examination of stakeholders and the opportunity they present. Journal of the Academy of Marketing Science, 39 (1), 158-174.

Davies, A., Titterington, A. J., \& Cochrane, C. (1995). Who buys organic food? A profile of the purchasers of organic food in Northern Ireland. British Food Journal, 97 (10), 17-23.

Demeter. (2014). Markenzeichen für biodynamische Qualität. Retrieved November 3 $3^{\text {rd }}, 2017$, from: http://www.demeter.de/verbraucher/ueber-uns/demeter-markenzeichen

Diercks, R. (1983): Alternativen im Landbau. Eine kritische Gesamtbilanz. Stuttart: Ulmer.

Eames, J. (2016). Agricultural Bacteriology. Wentworth Press: UK.

Fotopoulos, C. \& Krystallis, A. (2002). Purchasing motives and profile of the Green organic consumer: a countrywide survey, British Food Journal, 104 (9), 730-765.

Gracia, A. \& De Magistris, T. (2008). The demand for organic foods in the South of Italy: A discrete choice model. Food Policy, 33 (5), 387-397.

Grant, R. (2010). Contemporary strategy analysis. Hoboken, N.J.: Wiley. 
INTERNATIONAL JOURNAL OF ACADEMIC RESEARCH IN BUSINESS AND SOCIAL SCIENCES Vol. 8, No. 8, August 2018, E-ISSN: 2222-6990 C 2018 HRMARS

Hahn, T. \& Scheermesser, M. (2006). Approaches to corporate sustainability among German companies. Corporate Social Responsibility and Environmental Management, 13(3), 150-165.

Kuester, S. (2012). MKT 301: Strategic Marketing \& Marketing in Specific Industry.

Contexts, University of Mannheim.

Lohr, L. (2005). Economic, Social and Environmental Benefits Associated with US Organic Agriculture, Researching Sustainable Systems: First Scientific Conference of the International Society of Organic Agriculture Research, Adelaide: Australia.

Oekolandbau. (2015). Geschichte und Richtungen des ökologischen Landbaus. Retrieved January $20^{\text {th }}$, 2017, from: https://www.oekolandbau.de/erzeuger/grundlagen/zahlen-datenfakten/hintergruend/geschichte-des-oekolandbaus/

Oekolandbau. (2016). Bio-Siegel. Retrieved February 2 ${ }^{\text {nd }}$, 2017, from: https://www.oekolandbau.de/bio-siegel/

Organicstyle. (2010). Ist ein Unterschied zwischen bio und öko. Retrieved January $4^{\text {th }}, 2017$, from: http://www.organicstyle.de/bio-oeko.

Statista. (2015). Umsatz mit Bio-Lebensmitteln in Deutschland in den Jahren 2000 bis 2015.

Retrieved November 24 ${ }^{\text {th }}, 2017$, from:

http://de.statista.com/statistik/daten/studie/4109/umfrage/bio-lebensmittel-umsatz-zeitreihe/

Padel, S. \& Foster, C. (2005). Exploring the gap between attitudes and behavior. British Food Journal, 107 (8), 606-625.

Robles, R., Vannini, L., De La Puente, T. \& Fernandez-Revuelta, J.J. (2005) Consumer attitudes behind organic foods perception: An illustration in a Spanish área. Retrieved January $13^{\text {th }}, 2017$, from: http://www.caae2005.dk/POSTER_PAPERS/SS22 808 DelaPuente.pdf

Stolz, H., Jahrl, I., Baumgart, L. \& Schneider, F. (2010). Sensory Experiences and Expectations of Organic Food. ECROPOLIS - Project -Report WP 4.2.

Thøgersen, J., Haugaard, P. \& Olesen, A. (2010). Consumer responses to ecolabels. European Journal of Marketing, 44 (11/12), 1787-1810.

Umweltbundesamt. (2015). Ökologischer Landbau. Retrieved January $7^{\text {th }}, 2017$, from: http://www.umweltbundesamt.de/daten/land-forstwirtschaft/landwirtschaft/oekologischer-

$\underline{\text { landbau }}$

Visschers, V., Tobler, C., Cousin, M. E., Brunner, T., Orlow, P. \& Siegrist., C. (2009). Konsumverhalten und Foerderung des Bundesamtes fuer Umwelt BAFU. Zurich: ETH Zurich

Wier, M. \& Calverley, C. (2002). Market potential for organic foods in Europe. British Food Journal, 104 (1), 45-62.

Willer, H. \& Kilcher, L. (2014). The world of Organic Agriculture. Statistics and Emerging Trends 2014. FiBL-IFOAM Report. IFOAM, Bonn and Frick.

Zanoli, R., Baehr, M., Botschen, M., Laberenz, H., Naspetti, S., \& Thelen, E., (2004). The European Consumer and Organic Food. Organic Marketing Initiatives and Rural Development: Vol. 4, Aberystwyth, UK. 